\title{
PROFESSOR ZIGMAN BRENER
}

A Ciência Brasileira está de luto. Faleceu no dia 23 de setembro de 2002, no Hospital Felício Rocho, em Belo Horizonte, vítima de pneumonia, após longa enfermidade, o Professor Dr. Zigman Brener, um dos maiores Parasitologistas do País.

Zigman, filho único de pais pobres, de origem judia, nasceu na cidade de São Paulo, em 7 de setembro de 1928. Aos 13 anos de idade, em 1941, juntamente com seus pais Isaac Brenner e Ana Marcinovsky -, transferiram-se para Belo Horizonte, residindo, inicialmente, no Bairro Calafate e, posteriormente, no Bairro Carlos Prates, onde fixaram residência. Freqüentou os cursos ginasial e científico no Ginásio público Mineiro que contava, à época, com os melhores professores de Belo Horizonte. Em 1948, foi classificado em primeiro lugar no vestibular para Medicina. Diplomouse em 1953; seis meses depois, casou-se com Adélia em 24 de junho de 1954. Tiveram duas filhas - Stela e Marta - e cinco netos: Tatiana e Henrique Brener Vetchenko, filhos de Stela e, Hanna, Daniel e Sarah Brener Mockdece, filhos de Marta. Após o casamento, continuou residindo com seus pais até sua viajem para a Suíça.

Embora tenha clinicado como cardiologista por um ano, sua opção pela carreira científica já estava definida. Durante o seu curso médico já publicara cerca de vinte trabalhos. Inicialmente trabalhou em esquistossomose e leishmaniose, mas, posteriormente, orientou seus estudos para a Doença de Chagas, experimental e humana. Em 1955, o convite do Professor Amilcar Viana Martins para ser assistente seu na Cátedra de Parasitologia da Faculdade de Farmácia da UFMG bem como para integrar o quadro de pesquisadores do recém-criado Instituto Nacional de Endemias Rurais, veio ao encontro de seu sonho. O encontro, então, com o Dr. José Pellegrino foi providencial, reforçando sua decisão de seguir a carreira científica.

A convite do Laboratório Hoffman La Roche, ambos estagiaram um ano em seus laboratórios em Basiléia, Suíça, com a finalidade de organizar protocolos destinados ao teste de drogas que seriam desenvolvidas pelo Laboratório La Roche para doenças parasitárias.

Regressando ao Brasil, fixou residência na Capital, à rua Monte Branco, 232, no bairro Nova Suíça.
The Brazilian Science is on mourning. Recently died of pneumonia, at the Felicio Roxo Hospital, in Belo Horizonte, after long disease, Professor Zigman Brener, one of the greatest Parasitologists of this country. His burial was at the Jewish Cemetery.

Zigman, single son of poor parents of Jewish origin, was born in São Paulo city, on September 7th, 1928.

When he was 11 years old, together with his parents, Isaac Brenner e Ana Marcinovsky, they moved to Belo Horizonte, living initially at the Calafate neighborhood and later the family, moved to Carlos Prates. For the middle and high school he studied at the Mineiro School, which in that period had the best teachers of Belo Horizonte. In 1948 he got the first place on the selection for Medical School. He graduated in 1953 and 6 months later he married Adélia, on June 24th, 1954. They had two daughters, Stela and Marta and five grandchildren - Tatiana and Henrique Brener, from Stela and Hanna, Daniel and Sarah Brener Mockdece, from their daughter Marta. After the marriage he kept living with his parents until he traveled to Switzerland.

Although he worked with Medicine for a year, apparently he already had the inclination for the scientific carrier, what was showed by the publication of 20 articles during his undergraduate program. In 1955 he was invited by the Professor Amilcar Viana Martins to be his assistant on Parasitology at the College of Pharmacy and be part of the researchers team of the newly created National Institute of Rural Endemies, what he always dreamt. By getting to know Dr. José Pellegrino his decision to follow the scientific carrier was more reinforced.

He was then invited by the Hoffman La Roche Laboratories and together with Dr. José Pellegrino they did a tour of duty at Basileia, Switzerland with the intent of organizing protocols to test drugs, developed by that company, for parasitological diseases.

Back to Brazil he resided at 232, Monte Branco Street, Nova Suiça, in Belo Horizonte. He decided then to concentrate his efforts on Chagas disease, while Pellegrino decided to work with schistossomiasis. Both were successful and internationally respected for their leading publications on those two diseases. Zigman used to share his time between the René Rachou Research 
Resolveu concentrar seus esforços no estudo da Doença de Chagas, enquanto que Pellegrino decidira pelo estudo da esquistossomose. Ambos tiveram sucesso e foram respeitados internacionalmente pelas publicações de vanguarda nas respectivas áreas. Zigman dividia seu tempo entre o Centro de Pesquisas René Rachou, antigamente Instituto de Endemias Rurais e a Universidade Federal de Minas Gerais (UFMG), a princípio como Catedrático de Parasitologia da Faculdade de Farmácia e, posteriormente, com a criação do Instituto de Ciências Biológicas (ICB) em 1967, como titular do Departamento de Parasitologia.

Conheci o Prof. Zigman quando o ICB ainda funcionava na Faculdade de Medicina; eu pertencia ao Departamento de Bioquímica, no quarto andar e, Zigman ao Departamento de Parasitologia, no terceiro. $\mathrm{A}$ atividade científica muito nos aproximou, e, à época, propus uma colaboração para desenvolvimento de um clone da cepa CL, posteriormente abordado experimentalmente, com sucesso, por estudante de pósgraduação, em seu Laboratório. Maior intimidade com Zigman, contudo, só ocorreu quando fui convidado por ele, então Diretor do Centro de Pesquisas René Rachou, e o Naftale Katz, para dirigir o laboratório de Imunologia, após minha aposentadoria na UFMG, em 1980. Sempre me impressionou pela sua competência, capacidade criativa e obsessão pelo trabalho. Freqüentava o Laboratório inclusive aos sábados e domingos. Sua principal linha de pesquisa foi a terapêutica experimental da doença de Chagas. Demonstrou, pela primeira vez, a atividade dos nitrofuranos na cura de camundongos experimentalmente infectados com Trypanosoma cruzi.

Além de sua atividade de laboratório que resultou na publicação de cerca de 220 trabalhos, três livros, inúmeros capítulos e duas teses - uma de livre-docência na Cadeira de Zoologia e Parasitologia da Faculdade de Odontologia e Farmácia da UFMG, em 1961, e outra para obtenção da Cátedra na mesma Instituição, em 1962. Participou ativamente na formação de pessoal orientando 23 teses de mestrado e cinco de doutorado, todas relacionadas com a Doenças de Chagas. Um de seus principais trabalhos foi realizado em colaboração com a Dra. Antoniana Krettli. Descobriram, em camundongos infectados experimentalmente, anticorpos induzidos por componentes protéicos da superfície de tripomastigota sanguíneo - anticorpos líticos - que desapareciam, após quimioterapia, muito antes dos anticorpos convencionais. Esse anticorpo tem sido utilizado por muitos pesquisadores para monitorar a cura da doença de Chagas, após tratamento.

Com relação às suas atividades extralaboratório, participou do Colegiado de várias Instituições de fomento à pesquisa. Foi membro e posteriormente Presidente do Comitê de Doença de Chagas do "TDR/ Special Program for Research and Training in Tropical Diseases" em Genebra, destinado a auxiliar projetos mantidos pela Organização Mundial de Saúde. Foi um dos articuladores para criação, no CNPq, de um fundo destinado ao desenvolvimento de pesquisa multidisciplinar, denominado Programa Integrado de Doenças Endêmicas (PIDE) que surgiu simultânea e independentemente do TDR, em 1974. O resultado desse esforço foi a formação
Center, previous Institute of Rural Endemies and the Federal University of Minas Gerais (UFMG), first as a Professor of Parasitology of the College of Pharmacy, since 1962 and later, in 1967, as of chair of the Department of Parasitology, with the creation of the Institute of Biological Sciences (ICB).

I met Zigman when the ICB was still part of the School of Medicine, with the Department of Biochemistry, where I used to work, located at the fourth floor and the Department of Parasitology, on the third floor. The scientific activity made us closer to each other. That time I proposed Zigman a project to develop a clone of the CL strain, later followed with success by a student, in his laboratory. Greater intimacy with Zigman happened when he invited me, when he was the Director of the René Rachou Research Center together with Dr. Naftale Katz, to direct an Immunology Laboratory after I retired from the University, in 1980. What always impressed me were his competence, creativity and obsession for his work, frequently seen on duty, even Saturdays and Sundays. His main research area was on the experimental therapeutics for the Chagas Disease. He demonstrated the activity of nitrofuranes on the cure of mice experimentally infected with Trypanossoma cruzi.

Besides his activity at the laboratory, which resulted on the publication of 220 articles, three books, many book chapters and two thesis, one to be docent on Zoology and Parasitology Departament at the Dentistry and Pharmacy School of Federal University of Minas Gerais in 1961, and the other to be the chairman at the same Institution, in 1962. He actively participated on the formation of graduate students with 23 M.Sc. and five Ph.D. theses, all related with Trypanossoma cruzi or Chagas disease. One of his main publication was in collaboration with $\mathrm{Dr}^{\mathrm{a}}$. Antoniana Krettli, researcher of the CPqRR, showing that, in experimentally infected mice, an antibody that was induced by a proteic component of the surface of the blood trypomastigote, which was called lythic antibody, would disappear after chemotherapy, long before the conventional antibodies. This antibody has been used to monitor the cure of Chagas disease, after treatment.

In relation to his activities outside the laboratory he participated in the Review Board of many institutions related to research funding. He was a member and then President of the Chagas Disease Committee of the TDR/ Special Program for Research and Training in Tropical Disease, in Geneva, to fund grants of the WHO. He was one of the articulators to create the CNPq, originated from a fund to develop a multidisciplinary research named Integrated Program to Endemic Diseases (PIDE) that was established simultaneously and independently form the TDR, in 1974. The result of those efforts was the creation of many Excellency Groups that today participate in many Research Institutes in the country. I was also benefited with this Program, when I had the opportunity to create and equipped a laboratory at the 
de inúmeros grupos de excelência, que hoje trabalham em diversas Instituições de Pesquisa do País. Eu mesmo fui beneficiado com auxilio desse Programa, quando tive oportunidade de instalar e equipar um laboratório no Departamento de Bioquímica e Imunologia da UFMG destinado a estudos relacionados com esquistossomose.

Zigman era filiado a várias Sociedades Ciêntíficas: era membro Titular da Academia Brasileira de Ciências; Presidente do Conselho Curador da Fundação Ezequiel Dias (FUNED) da Secretaria de Saúde do Estado de Minas Gerais (1992-1995); Membro fundador da Sociedade Brasileira de Medicina Tropical; membro das Sociedades Brasileiras de Parasitologia e de Protozoologia e da Federação Latino-Americana de Parasitologia; membro Honorário da Sociedade Internacional de Protozoologia.

Recebeu inúmeras homenagens e medalhas: Medalha Cultural Pirajá da Silva; Medalha Cultural Gaspar Vianna; Medalha Instituto Adolpho Lutz; Medalha Universidad de Caracas; Medalha da Sociedade Brasileira para o Progresso da Ciência; Medalha do $1^{\circ}$ Centenário de Carlos Chagas; Medalha Conselho Nacional de Desenvolvimento Científico e Tecnológico; Medalha Samuel Pessoa, 1998; recebeu Prêmio Fundação Oswaldo Cruz/Grupo EMS-Sigma Pharma de Ciếncia \& Tecnologia em Saúde, na categoria de Pesquisador Sênior, 2000; era Professor Emérito da UFMG e Membro da Ordem Nacional do Mérito Científico, na classe de Grã-Cruz.

Após 1997, com o agravamento de seu estado de saúde, suas atividades científicas reduziram-se drasticamente. Naquela época, eu regressava de uma viagem à área endêmica de esquistossomose, acompanhado do Dr. Aluízio Prata, que me perguntou se eu já havia observado as falhas de memória do nosso grande amigo. Respondi afirmativamente, mas lhe confessei que eu ainda não tivera coragem de chamar a atenção do Zigman para o problema. O Prata, que ia permanecer no aeroporto da Pampulha por cerca de três horas aguardando o avião para Uberaba, pediu-me que entrasse em contato com ele solicitando sua ida ao aeroporto para se encontrarem. Depois desse contato soube que o Zigman consultara um neurologista que lhe comunicou o provável diagnóstico de mal de Alzheimer. Sua doença progrediu rapidamente. A princípio, ele ainda comparecia ao laboratório à tarde, por uma ou duas horas, nos dias de sua fisioterapia, quando freqüentemente me visitava em minha sala. Mas, com a deterioração de sua memória, já não conseguia mais manter conversação. Costumava visitá-lo de quinze em quinze dias, em sua residência. A princípio, quando eu chegava ele me sorria; mais tarde, aparentemente, já não mais me reconhecia.

Sua perda é lamentável e teve repercussão internacional. A direção do Instituto Pasteur, em carta enviada ao Dr. George dos Reis, Presidente da Sociedade de Imunologia, assim expressou seus sentimentos:

\section{"Monsieur.}

L'Institut Pasteur a été extrêmement peiné d'apprendre le décès de l'éminent Professeur Zigman Brener, du Centre
Department of Biochemistry and Immunology at the UFMG to study schistossomiasis.

Zigman was a member of many Scientific Societies: member of the Brazilian National Academy of Sciences, President of the Curator Council of the Ezequiel Dias Foundation (FUNED) of the Health Department of Minas Gerais State (1992-1995); Founder Member of the Brazilian Society of Tropical Medicine; member of the Brazilian Society of Protozoology and of the Latin American Federation of Parasitology; Honorary Member of the International Society of Protozoology.

He received many honors and medals: Cultural Medal Pirajá da Silva; Cultural Medal Gaspar Vianna; Adolpho Lutz Medal; Universidad de Caracas Medal; Brazilian Society to the Progress of Science Medal; First Centennary of Carlos Chagas Medal; National Council of Scientific and Technological Development Medal; Samuel Pessoa Medal, 1998. Oswaldo Cruz Foundation/ EMS-Sigma Pharma Group on Science and Health Technology Award as Senior Researcher, 2000. He was Emerit Professor of the UFMG and Member of the National Order of Scientific Merit, as Grã-Cruz.

After 1997 with the exacerbation of his disease, Zigman's activities were drastically reduced. That time, I was returning from a trip on a schistossomiasis endemic area, with Dr. Aluízio Prata, when who asked if I had noticed his lack of memory. I answered affirmatively but I confessed that I have not had a chance to talk with Zigman about that problem. Prata who had to wait to his next flight for three hours at the Pampulha Airport asked me to contact Zigman and ask him to come to the airport and meet him there. After this meeting, Zigman consulted a Neurologist who gave him the probable diagnosis of Alzheimer. His disease has progressed very quickly. In the beginning he used to come to the lab in the afternoons for one or two hours, when he had physiotherapy, and used to come and visit in my room. But with his memory deterioration he could not talk anymore. I used to visit him every other week in his place. In the beginning when I arrived he used to smile at me, but later, apparently he would not recognize me anymore.

His loss is regrettable. The Institute Pasteur Presidency, in a letter sent to Dr. George dos Reis, President of the Society of Immunology, expressed his feelings by saying:

\section{"Monsieur.}

L'Institut Pasteur a été extrêmement peiné d'apprendre le décès de l'éminent Professeur Zigman Brener, du Centre de Recherches René Rachou, FIOCRUZ, survenu le 23 septembre dernier, à Belo Horizonte.

La notoriété scientifique du Professeur Brener a franchi I'Atlantique jusqu'à notre maison: il a 
de Recherches René Rachou, FIOCRUZ, survenu le 23 septembre dernier, à Belo Horizonte.

La notoriété scientifique du Professeur Brener a franchi I'Atlantique jusqu'à notre maison: il a formé plusieurs élèves de renom venus travailler un jour à l'Institut Pasteur et a fortement contribué à mettre en place dans notre Institut une école de pensée et de travail sur la Maladie de Chagas qui se développe depuis bientôt vingt ans. Par ailleurs, ses visites et séminaires à l'Institut et sa grande culture ont suscité une réflexion fructueuse dans le domaine de I'Immunologie Parasitaire et de la chimiothérapie. II laissera derrière lui une oeuvre scientifique féconde et un large impact qui génère et générera l'enthousiasme scientifique chez beaucoup de ses lecteurs à travers le monde.

La Direction Internationale de l'Institut Pasteur, la Coordination de la Coopération AMSUD/Pasteur, ainsi que tous les collègues pasteuriens du Professeur Brener, s'associent à sa famille ainsi qu'à la Société Bresilienne d'Immunologie et à l'Académie Brésilienne de Sciences pour le deuil causé par la perte de cette personnalité exceptionnelle tant du point de vue humain que des points de vue scietifique et académique.

Mme Michèle Boccoz, Directeur des Affaires Internationales,

\section{Institut Pasteur."}

Zigman sempre será lembrado pela sua personalidade, competência e capacidade de trabalho. Ficará na História da UFMG e do Centro de Pesquisas René Rachou. Perdemos um grande cientista e um grande amigo. formé plusieurs élèves de renom venus travailler un jour à l'Institut Pasteur et a fortement contribué à mettre en place dans notre Institut une école de pensée et de travail sur la Maladie de Chagas qui se développe depuis bientôt vingt ans. Par ailleurs, ses visites et séminaires à l'Institut et sa grande culture ont suscité une réflexion fructueuse dans le domaine de l'Immunologie Parasitaire et de la chimiothérapie. II laissera derrière lui une oeuvre scientifique féconde et un large impact qui génère et générera l'enthousiasme scientifique chez beaucoup de ses lecteurs à travers le monde.

La Direction Internationale de l'Institut Pasteur, la Coordination de la Coopération AMSUD/Pasteur, ainsique tous les collègues pasteuriens du Professeur Brener, s'associent à sa famille ainsi qu'à la Société Bresilienne d'Immunologie et à l'Académie Brésilienne de Sciences pour le deuil causé par la perte de cette personnalité exceptionnelle tant du point de vue humain que des points de vue scietifique et académique.

Mme Michèle Boccoz, Directeur des Affaires Internationales,

\section{Institut Pasteur."}

He will always be remembered by his personality, competence, and work capacity. He will definitely be in the History of the UFMG and of the Research Center René Rachou. He made several friends in the scientific community. We lost a great scientist and a great friend.

Prof. Giovanni Gazinelli 